International Review of Research in Open and Distributed Learning Volume 21, Number 1

January - 2020

\title{
Open to Open? An Exploration of Textbook Preferences and Strategies to Offset Textbook Costs for Online Versus On-Campus Students
}

Talea Anderson and Carrie Cuttler

Washington State University

\begin{abstract}
As open textbook initiatives are on the rise, a burgeoning literature has begun exploring student perceptions of openly licensed textbooks used in higher education. Most of this research has lacked consideration of potential differences in the perceptions of onlineand on-campus students and has failed to include a control group of students using traditional textbooks. Therefore, the authors employed a 2 x 2 design to directly compare perceptions of online students with on-campus students assigned either open or traditional textbooks. Students $(\mathrm{N}=925)$ enrolled in multiple sections of psychology courses at a midsized R1 institution completed a survey on their perceptions of their particular book's format and features, as well as strategies they typically employ to offset the cost of expensive course materials. The results revealed that online and on-campus students report disparate strategies for offsetting the high costs of textbooks, different preferences in textbook formats (print versus digital versus both) when cost is not a factor, and differences in their ratings of the importance of various textbook features. Moreover, the results indicate that the use of open textbooks may increase preference for free digital textbooks over paid printed textbooks. Based on these results, the authors suggest that campuses might consider providing customized support to different student populations as open textbook initiatives gain in popularity on university campuses. Additionally, they suggest that prior exposure to open textbooks may increase students' willingness to use openly licensed materials in future courses. They recommend future research on this question, using a longitudinal within-subjects designs.
\end{abstract}

Keywords: open educational resources, open textbooks, online education, distance education 


\section{Introduction}

In 2015, Washington State University (WSU) - a midsized R1 institution—created the Course Materials Cost Reduction Task Force to address concerns voiced by the associated student body about the high cost of course materials. This task force is part of a larger trend in higher education, as administrators, students, and faculty have become increasingly concerned about the rise in the cost of course materials. An NBCNews study in 2015 showed that textbook prices had increased 1,041\% since 1977, far outstripping inflation in the Consumer Price Index (Popken, 2015). Surveys suggest that this cost inflation negatively impacts student success; notably, in 2016 the Florida Virtual Campus survey of some 22,000 students found that 66.6\% had opted not to purchase a required textbook at some point due to cost, 37\% reported earning a poor grade due to cost of course materials, $19.8 \%$ reported failing a course, and $47.6 \%$ indicated that they had occasionally or frequently taken fewer courses due to cost (Florida Virtual Campus, 2016).

In response to these concerns, WSU organized the Course Materials Cost Reduction Task Force to communicate with key stakeholders on campus. The task force collaborated with university libraries and online education units to offer small-grant stipends to faculty members who wanted to reorganize courses around low-cost course materials or open educational resources (OER). OER were identified by the campus as openly licensed and freely available course materials that could be adopted, adapted, and integrated into courses (UNESCO, 2017). Overall, the task force issued recommendations to faculty to work with the campus bookstore and libraries to identify lower-cost options for students. As a public land-grant institution, WSU considered these measures a natural extension of its mission to open educational opportunities to underprivileged groups. The university comprises a central campus as well as four regional campuses and an online education program that attracts some 30,000 students. Depending on the campus, multicultural students comprise between $23 \%$ and $39 \%$ of the university's overall population. Some 1,680 incoming freshmen were first-generation students in 2017-an increase over previous years. Moreover, 1,879 of those who attend WSU are international students who have come from more than 100 countries. These demographics suggest a diverse student body with subpopulations that may be particularly sensitive to inflated course material costs.

As the affordability initiative has grown at WSU, interest has increased in understanding the differing needs of the students at the university. Previous researchers have attended to perceptions of students with respect to OER and digital texts but few have considered the needs of students receiving degrees as part of an online education program and how they may differ from those of students in an on-campus program. Certainly, some have suggested that student populations have different sensitivities when it comes to the cost of course materials. For instance, Petrides, Middleton-Detzner, Walling, and Weiss (2011) and Hilton, Robinson, Wiley, and Ackerman (2014) demonstrated that textbooks can be more expensive than tuition for community college students, meaning that this group is particularly keen to find solutions to cost inflation. The implication in this work is that non-traditional students with greater financial needs and work obligations may benefit more from the use of OER. The present study intends to further consider the needs of online and on-campus students using open digital and traditional commercial print course materials in their classes. 
More specifically, of interest for this study were differences in the perceptions of online and on-campus students toward their course materials after using either open or traditional texts. By distinguishing responses between online and on-campus students, this study intends to provide generalizable information to institutions of higher education wishing to support diverse student groups by providing OER.

\section{Literature Review}

To date, studies on student use of OER have focused primarily on course outcomes and reported perceptions of OER. While studies on course outcomes have generally involved comparisons of students using OER with those using traditional course materials, much of the research on students' perceptions has lacked a comparison group of students using (and rating) traditional texts. Moreover, little research has differentiated between online and on-campus students. That said, in J ohn Hilton's (2016) review of 16 studies on OER outcomes, he found little difference between performance indicators for students using OER and those using traditional texts. Similarly, numerous studies on student perceptions of OER have found majorities of students reporting that they rate OER equal to or better in quality compared to the traditional textbooks that they've previously used (Bliss, Robinson, Hilton, \&Wiley, 2013; Feldstein et al., 2012; Hilton, 2016; J hangiani \& J hangiani, 2017). In perception studies, students often cite affordability, presentation, accessibility, convenience, relevance, searchability, and portability as reasons for preferring OER over traditional print textbooks (Cooney, 2017; Feldstein et al., 2012; Hendricks, Reinsberg, \& Rieger, 2017; J hangiani \& J hangiani, 2017; Lindshield \& Adhikari, 2013; Ozdemir \& Hendricks, 2017; Petrides, Jimes, Middleton-Detzner, Walling, \& Weiss, 2011). Affordability typically tops the list of reasons why students prefer OER.

Some studies of performance in OER courses have asked students to comment specifically on their preferences for print versus digital resources. This question is relevant to the instructors who construct OER because these materials are typically delivered in digital format, although it is almost always possible to print the materials on demand. Students' preferences for print or digital content can be mixed, but a substantial number report preferring print resources over digital ones. Petrides and colleagues (2011) found in their analysis of the Community College Open Textbook Project that $77 \%$ of students preferred print resources, though they also praised the affordability and portability of OER. Illowsky, Hilton, Whiting, and Ackerman (2016) found that $48 \%$ of students using an open statistics textbook preferred to purchase a print copy, and $61 \%$ chose to print sections for class. J hangiani and J hangiani (2017) similarly found that $44 \%$ of students at post-secondary institutions in British Columbia preferred to use print material exclusively in class, while 16\% preferred digital only. J hangiani, Dastur, Le Grand, and Penner (2018) also focused on the print versus digital question in their recent study and found that students rated print OER more highly than digital OER or traditional coursematerials. These findings substantiated other studies that have not focused on OER exclusively but showed a preference among students for reading print as opposed to digital texts, although course outcomes did not differ markedly between the formats. Reasons often cited for disliking digital texts included difficulty in highlighting and annotating, quality concerns, and increased distraction in digital environments (Millar \& Schrier, 2015; Rockinson-Szapkiw, Courduff, Carter, \& Bennett, 2013; Shepperd, Grace, \& Koch, 2008; Woody, Daniel, \&Baker, 2010). 
Studies on student use of OER have, by and large, chosen not to consider online students in contrast to oncampus students, but some have hinted at the diverse populations served by open resources and resulting differences in student outcomes and perceptions. For instance, Colvard, Watson, and Park (2018) recently reported that students receiving financial aid, part-time students, and ethnic minorities benefited more from OER than those not receiving financial aid, full-time students, and white students. Further, in their study of OER use at Virginia State University, Feldstein and colleagues (2012) found that $70 \%$ of students preferred to read their textbook on a laptop or computer-an outcome that the authors found intriguing given that many were urban commuter students. The students in this study also reported that the leading barrier for accessing the OER was an inconsistent wireless connection. This barrier is substantial and speaks to the unique needs of students in the Virginia State study. Buzzetto-More, Guy, and Elobaid (2007) similarly spoke to the specialized needs of certain student populations when they remarked on the use of digital textbooks by students at historically black colleges and universities (HBCU). The HBCU students who responded to the survey had little prior experience with digital books, and the authors suggested that student backgrounds should be taken into account when providing course materials.

This research, while not directly applicable, provides a background for the present study, which will consider differences and similarities in online and on-campus students' perceptions of open and traditional textbooks at WSU. More specifically, the present study aimed to (1) compare strategies to offset textbook costs in online versus on-campus students, (2) compare online and on-campus students' preferences for digital versus print textbooks, (3) compare online and on-campus students' ratings of the importance of various textbook features (e.g., price, immediate access, portability, etc.). Further, the study included comparison groups of online and on-campus students using traditional textbooks to permit for exploration of the potential impacts of using open versus traditional textbooks on these preferences (Aim 2) and ratings (Aim 3).

\section{Method}

\section{Procedure}

The Office of Research Assurances found this study to be exempt from the need for Institutional Review Board review. A large sample of undergraduate students $(\mathrm{N}=1,133)$ were asked to complete an anonymous online survey in the Fall 2017 and Spring 2018 semesters. The survey required approximately 10-15 minutes to complete and students in sections with a response rate of $75 \%$ or higher were given a small number of bonus points.

\section{Materials}

Demographics. Participants were asked to input their age and indicate their gender, minority status, and status as a first-generation student. Further, they were asked to indicate their year of university, the number of courses they were currently enrolled in, and their overall GPA. 
Strategies to offset textbook costs. Participants were asked, "In which of the following ways has the cost of textbooks influenced you? (Check all that apply.)" This was followed by the 13 strategies to offset textbook costs shown in Table 2. Next, they were asked, "How often have you taken the following actions as a result of textbook costs?" The five strategies shown in Table 3 were presented and participants were asked to respond to each option using scale with the following response options: $0=\operatorname{Never}$ (0 Times), 1 = Rarely (1-2 Times), 2 =Sometimes (3-5 Times), 3 =Often (6-10 Times), and 4 =Very Often (More than 10 Times).

Preferences for print versus digital textbooks. Students who were assigned traditional textbooks could opt to purchase either a print or digital copy of their textbook. While only digital copies of the open textbooks were provided, students could print PDF versions of these textbooks. To determine how many used each option, participants were asked if they used a printed or digital copy of their assigned textbook or if they used both. They were then asked, "In general, would you rather have a free digital textbook or pay for a printed textbook?" As shown in Table 4, they were given three options for their response (free digital text, paid printed text, or no preference). Next, they were asked, "Assume cost is not a factor. Which of the following textbook formats would you prefer?" Once again, they were given three response options (print, digital, or both). Students who responded with the print option were asked to indicate the reason(s) for their preference for printed textbooks. They were provided with the list of six options (shown in the upper portion of Table 5) and were instructed to check all that applied. Students who responded with the digital option were asked to indicate the reason(s) for their preference for using digital textbooks. They were provided with a list of six options (shown in the lower portion of Table 5) and were instructed to check all that applied.

Finally, students in classes using open textbooks were asked to indicate how strongly they agreed with the statement, "I would have preferred to purchase a traditional textbook for this course," and students in classes using traditional textbooks were asked to indicate how strongly they agreed with the statement, "I would have preferred a free digital textbook for this course." All students were given a scale ranging from 1 $=$ Strongly disagree to $5=$ Strongly agree, to indicate their level of agreement.

Importance of textbook features. Participants were asked, "How important to you are the following features of your textbook?" They were shown the six options displayed in Table 6 and for each were asked to rate its importance using a scale ranging from $1=$ Of no importance at all to $5=$ Absolutely essential.

\section{Design}

A $2 \times 2$ between-subjects cross-sectional design was used to compare the responses of students assigned two different types of textbooks (traditional versus open) in two different types of learning environments (on-campus versus online). There was a total of three open textbooks and three traditional textbooks used in 15 different sections of various psychology classes. 


\section{Participants}

A total of 925 undergraduate psychology students completed the online survey, representing an overall response rate of $81.6 \%$. Participants ranged in age from 18 to $65(\mathrm{M}=24.45, \mathrm{SE}=0.25)$ and were predominantly female (82.2\%) and Caucasian (74.3\%). On average students were taking 4.80 (SE =0.83) courses and reported an average GPA of $3.25(\mathrm{SE}=0.02)$.

Of the 925 students who completed the survey, 363 were on-campus and were assigned a traditional textbook, 203 were on-campus and were assigned an open textbook, 181 were online students assigned a traditional textbook, and 178 were online students assigned an open textbook. Demographic and other sample characteristics for each of the four groups are provided in Table 1. As shown in the table, there was a higher percentage of females and first-generation students in the online classes than in the on-campus classes, and online students were significantly older and earned a significantly higher income than oncampus students. Online students and students assigned traditional textbooks were enrolled in significantly fewer courses than on-campus students and those assigned open textbooks, respectively. Finally, online students and those assigned open textbooks were more advanced in their education than on-campus students and those assigned traditional textbooks. Given these potentially confounding differences, gender, income, first-generation status, age, year in university, and number of currently enrolled courses will be entered as covariates in analyses involving comparisons of these groups.

\section{Results}

\section{Strategies to Offset Textbook Costs}

In order to determine whether online students report different strategies to offset textbook costs than students taking classes on campus, the overall percentages of onlineand on-campus students who endorsed particular strategies were computed. Hierarchical logistic regression analyses were then used to compare each set of percentages after statistically controlling for the potentially confounding differences in the demographic characteristics of these groups. As indicated in Table 2, online students were less likely than on-campus students to report purchasing used copies of textbooks from the campus bookstore, opting not to use a textbook, or sharing a textbook with a classmate. In contrast, online students were more likely than on-campus students to report buying from a source other than the campus store and renting a digital textbook. 
Table 1

Demographic Characteristics of the Four Groups

\begin{tabular}{|c|c|c|c|c|c|c|c|c|c|c|}
\hline & \multicolumn{2}{|c|}{ On campus } & \multicolumn{2}{|c|}{ Online } & \multicolumn{6}{|c|}{ Main effects and interactions } \\
\hline & \multirow{2}{*}{$\begin{array}{c}\text { Traditional } \\
\mathrm{N}=363\end{array}$} & \multirow{2}{*}{$\begin{array}{c}\text { Open } \\
N=203\end{array}$} & \multirow{2}{*}{$\begin{array}{c}\text { Traditional } \\
\mathrm{N}=181\end{array}$} & \multirow{2}{*}{$\begin{array}{c}\text { Open } \\
N=178\end{array}$} & \multicolumn{3}{|c|}{ Main Effect textbook } & \multicolumn{3}{|c|}{ Main effect environment } \\
\hline & & & & & $\chi^{2}$ & $\mathrm{p}$ & OR & $\chi^{2}$ & $\mathrm{p}$ & OR \\
\hline \multirow[t]{2}{*}{$\%$ Female } & $79.3 \%$ & $80.1 \%$ & $87.3 \%$ & $85.3 \%$ & 0.41 & .84 & 0.96 & 6.62 & .01 & 0.61 \\
\hline & & & & & & \multicolumn{2}{|c|}{ Interaction } & 0.28 & .59 & 1.23 \\
\hline \multirow[t]{2}{*}{ \% Caucasian } & $76.3 \%$ & $70.2 \%$ & $75.7 \%$ & $73.7 \%$ & 2.21 & .14 & 0.79 & 0.17 & .68 & 0.94 \\
\hline & & & & & & \multicolumn{2}{|c|}{ Interaction } & 0.40 & .53 & 0.82 \\
\hline \multirow[t]{4}{*}{$\% 1^{\text {st }}$ Generation } & $29.3 \%$ & $32.5 \%$ & $49.7 \%$ & $38.6 \%$ & 0.64 & .42 & 1.12 & 18.43 & $<.001$ & 1.84 \\
\hline & & & & & & \multicolumn{2}{|c|}{ Interaction } & 4.43 & .04 & 0.55 \\
\hline & & & & & \multicolumn{3}{|c|}{ Main effect textbook } & \multicolumn{3}{|c|}{ Main effect environment } \\
\hline & & & & & $\mathrm{F}$ & $\mathrm{p}$ & $\eta_{\mathrm{p}}^{2}$ & $\mathrm{~F}$ & $\mathrm{p}$ & $\eta_{\mathrm{p}}^{2}$ \\
\hline \multirow[t]{2}{*}{ Age } & $20.31(0.30)$ & $20.97(0.40)$ & $30.96(0.42)$ & $30.07(0.42)$ & 0.09 & .78 & .000 & 650.73 & $<.001$ & .42 \\
\hline & & & & & & \multicolumn{2}{|c|}{ Interaction } & 4.05 & .04 & .004 \\
\hline \multirow[t]{2}{*}{ University Year } & $2.92(0.05)$ & $3.29(0.07)$ & $3.13(0.08)$ & $3.48(0.08)$ & 26.54 & $<.001$ & .03 & 8.37 & .004 & .009 \\
\hline & & & & & & \multicolumn{2}{|c|}{ Interaction } & 0.03 & .87 & .000 \\
\hline \multirow[t]{2}{*}{ \# of Courses } & $5.10(0.13)$ & $5.94(0.17)$ & $3.79(0.18)$ & $3.91(0.18)$ & 8.58 & .003 & .009 & 103.40 & $<.001$ & .10 \\
\hline & & & & & & \multicolumn{2}{|c|}{ Interaction } & 4.80 & .03 & .005 \\
\hline \multirow[t]{2}{*}{ GPA } & $3.26(0.03)$ & $3.21(0.04)$ & $3.28(0.04)$ & $3.24(0.04)$ & 1.09 & .30 & .001 & 0.59 & .44 & .001 \\
\hline & & & & & & \multicolumn{2}{|c|}{ Interaction } & 0.004 & .95 & .000 \\
\hline \multirow[t]{2}{*}{ Income/Week } & $\$ 150.04$ & $\$ 217.81$ & $\$ 431.91$ & $\$ 473.31$ & 1.86 & .17 & .002 & 25.63 & $<.001$ & .03 \\
\hline & (33.13) & (42.62) & (48.76) & (47.93) & & \multicolumn{2}{|c|}{ Interaction } & 0.11 & .74 & .000 \\
\hline
\end{tabular}

Note. Percentages are presented for nominal variables. Means are presented with standard errors in parentheses for continuous variables. OR $=$ odds ratio, $\eta_{\mathrm{p}}{ }^{2}=$ partial eta squared (effect size indicator). 
Table 2

Comparisons of the Strategies Used to Offset Textbook Costs Endorsed by Online Versus On- Campus Students

\begin{tabular}{lccccc}
\hline & $\begin{array}{c}\text { On campus } \\
(\mathrm{N}=566)\end{array}$ & $\begin{array}{c}\text { Online } \\
(\mathrm{N}=359)\end{array}$ & $\chi^{2}$ & $\mathrm{p}$ & $\Delta \mathrm{R}^{2}$ \\
\hline Bought used copies from campus store & $77.6 \%$ & $59.3 \%$ & 5.96 & .01 & .009 \\
Rented printed text & $64.8 \%$ & $60.7 \%$ & 0.01 & .91 & .000 \\
Bought from source other than campus store & $61.0 \%$ & $75.8 \%$ & 6.62 & .01 & .01 \\
Bought a digital version & $47.7 \%$ & $43.2 \%$ & 3.41 & .06 & .006 \\
Didn't use a textbook & $44.9 \%$ & $12 \%$ & 22.02 & $<.001$ & .03 \\
Sold my used textbook & $34.6 \%$ & $27.6 \%$ & 0.73 & .39 & .002 \\
Shared a book with classmate & $33.6 \%$ & $6.7 \%$ & 26.22 & $<.001$ & .04 \\
Rented a digital text & $25.4 \%$ & $37.3 \%$ & 11.17 & $<.001$ & .018 \\
Downloaded a text from the internet & $23.7 \%$ & $15.6 \%$ & 0.23 & .63 & .001 \\
Used a library reserved copy & $8.8 \%$ & $3.9 \%$ & 2.92 & .09 & .008 \\
Nothing; I've purchase them at regular cost & $2.8 \%$ & $5 \%$ & 2.13 & .14 & .009 \\
Used an interlibrary loan & $2.3 \%$ & $1.4 \%$ & 1.73 & .19 & .012 \\
Stole my textbook & $0.5 \%$ & $0.6 \%$ & 0.19 & .66 & .003 \\
\hline
\end{tabular}

Note. Percentages represent overall percentages (without effects of covariates removed); $\chi^{2}=$ chi-square statistic for the difference between the groups after controlling for potentially confounding demographic characteristics (gender, age, income, first-generation status, year in university, number of courses); $\Delta \mathrm{R}^{2}=$ change in $\mathrm{R}^{2}$ associated with adding learning environment to the hierarchical logistic regression models (i.e., effect size indicator).

A multivariate analysis of covariance (MANCOVA) was used next to compare how frequently online versus on-campus students reported engaging in various strategies, while controlling for the potentially confounding demographic variables. The results revealed a significant overall difference in the two groups, Wilks $\lambda=0.93, \mathrm{~F}=12.95, \mathrm{p}<.001, \eta_{\mathrm{p}}{ }^{2}=.07$. As depicted in Table 3, on-campus students reported not purchasing the required textbook significantly more often than online students. In contrast, online students reported not registering for specific courses significantly more frequently than on-campus students. 
Table 3

Comparisons of the Frequency of Engaging in Various Strategies to Offset Textbook Costs in OnlineVersus On-Campus Students

\begin{tabular}{lccccc}
\hline & $\begin{array}{c}\text { On campus } \\
(\mathrm{N}=511)\end{array}$ & $\begin{array}{c}\text { Online } \\
(\mathrm{N}=325)\end{array}$ & $\mathrm{F}$ & $\mathrm{p}$ & $\eta_{\mathrm{p}}{ }^{2}$ \\
\hline Not purchased the required textbook & $1.51(0.06)$ & $0.75(0.05)$ & 43.37 & $<.001$ & .05 \\
Earned a poor grade because I could not & $0.59(0.05)$ & $0.45(0.06)$ & 2.52 & .11 & .003 \\
afford to buy the textbook & & & & \\
Not registered for a specific course & $0.31(0.04)$ & $0.56(0.06)$ & 8.62 & .003 & .01 \\
Taken fewer courses & $0.35(0.04)$ & $0.49(0.06)$ & 3.25 & .07 & .004 \\
Dropped or withdrawn from a course & $0.24(0.03)$ & $0.32(0.05)$ & 1.34 & .25 & .002 \\
\hline
\end{tabular}

Note. Marginal means (with effects of covariates removed) are presented with standard errors in parentheses; 0 indicates a response of never, 1 indicates a response of rarely (1-2 times), and 2 indicates a response of sometimes (35 times). F statistics represent comparisons of the two groups after controlling for differences in demographic characteristics (gender, age, first-generation status, year in university, number of courses); $\eta_{\mathrm{p}}{ }^{2}=$ partial eta squared (effect size indicator).

\section{Textbook Preferences}

In order to determine whether there were differences in the formats of textbooks students in the four groups used, and differences in their preferences for digital versus print textbooks, the overall percentages of students in each group who endorsed each option were first computed. Hierarchical logistic regression analyses were then used to examine the main effects of learning environment (on-campus versus online), the main effects of textbook type assigned (traditional versus open), as well as environment x textbook type interactions, after controlling for the potentially confounding differences in the demographic characteristics of the four groups.

Table 4 shows the overall percentages and the results of the hierarchical logistic regression analyses used to compare these percentages. Not surprisingly, students who were assigned open textbooks were 40 times (1/ 0.025) less likely to report using printed textbooks and were 31.50 times more likely to report using a digital format than those assigned traditional textbooks. Further, on-campus students were 3.33 times (1/ 0.30) less likely than online students to report using both formats (see upper portion of Table 4).

While there were no significant differences in online and on-campus students' general textbook format preferences, overall students reported preferring a free digital textbook to a paid printed textbook (see middle portion of Table 4). The results further revealed that students assigned open textbooks were 2.07 times more likely to report preferring a free digital textbook and were 2.63 times (1/0.38) less likely to report preferring to pay for a printed textbook than students assigned traditional textbooks.

Assuming cost was not a factor, most students reported preferring printed textbooks (see lower portion of Table 4). However, students in classes using open textbooks were 1.88 times (1/0.53) less likely to report 
preferring printed textbooks, were 1.58 times more likely to report preferring digital textbooks, and were 1.61 times more likely to report preferring both formats than students in classes using traditional textbooks. Finally, on-campus students were 1.58 times more likely to report preferring printed textbooks and were 1.79 times less likely to report preferring both formats than online students. 
Table 4

Use of and Preferences for Digital Versus Printed Textbooks Across the Four Groups

\begin{tabular}{|c|c|c|c|c|c|c|c|c|c|c|}
\hline & \multicolumn{2}{|c|}{ On campus } & \multicolumn{2}{|c|}{ Online } & \multicolumn{6}{|c|}{ Main effects and interactions } \\
\hline & \multirow{2}{*}{$\begin{array}{c}\text { Traditional } \\
\mathrm{N}=353\end{array}$} & \multirow{2}{*}{$\begin{array}{c}\text { Open } \\
\mathrm{N}=138\end{array}$} & \multirow{2}{*}{$\begin{array}{c}\text { Traditional } \\
\mathrm{N}=181\end{array}$} & \multirow{2}{*}{$\begin{array}{c}\text { Open } \\
\mathrm{N}=177\end{array}$} & \multicolumn{3}{|c|}{ Main effect textbook } & \multicolumn{3}{|c|}{ Main effect environment } \\
\hline & & & & & $\chi^{2}$ & $\mathrm{p}$ & OR & $\chi^{2}$ & $\mathrm{p}$ & OR \\
\hline \multicolumn{11}{|l|}{ Format used } \\
\hline \multirow[t]{2}{*}{ Print } & $81.9 \%$ & $7.9 \%$ & $73.5 \%$ & $8.5 \%$ & 265.85 & $<.001$ & 0.025 & 0.15 & .70 & 0.90 \\
\hline & & & & & & & raction & 1.17 & .28 & 0.62 \\
\hline \multirow[t]{2}{*}{ Digital } & $15.9 \%$ & $87.1 \%$ & $12.7 \%$ & $77.4 \%$ & 278.89 & $<.001$ & 31.50 & 4.34 & .04 & 1.78 \\
\hline & & & & & & & raction & 0.83 & .36 & 1.45 \\
\hline \multirow[t]{2}{*}{ Both } & $2.3 \%$ & $5.0 \%$ & $13.8 \%$ & $14.1 \%$ & 0.83 & .36 & 1.29 & 10.51 & .001 & 0.30 \\
\hline & & & & & & & raction & 1.03 & .31 & 1.83 \\
\hline \multicolumn{11}{|l|}{ General preference } \\
\hline \multirow[t]{2}{*}{ Paid print } & $16.8 \%$ & $5.9 \%$ & $21.0 \%$ & $9.0 \%$ & 15.31 & $<.001$ & 0.38 & 0.15 & .70 & 1.00 \\
\hline & & & & & & & raction & 0.20 & .65 & 0.80 \\
\hline \multirow[t]{2}{*}{ Free digital } & $78.2 \%$ & $88.1 \%$ & $69.1 \% \%$ & $86.4 \%$ & 13.29 & $<.001$ & 2.07 & 1.70 & .19 & 1.40 \\
\hline & & & & & & & raction & 0.72 & .40 & 0.72 \\
\hline \multirow[t]{2}{*}{ No preference } & $5.0 \%$ & $6.0 \%$ & $9.9 \%$ & $4.5 \%$ & 0.17 & .67 & 0.88 & 2.51 & .11 & 0.53 \\
\hline & & & & & & & raction & 3.82 & .051 & 3.30 \\
\hline \multicolumn{11}{|c|}{ Preferred format if cost not a factor } \\
\hline \multirow[t]{2}{*}{ Print } & $68.8 \%$ & $53.2 \%$ & $59.1 \%$ & $46.0 \%$ & 18.61 & $<.001$ & 0.53 & 5.07 & 0.02 & 1.58 \\
\hline & & & & & & & raction & 0.28 & .60 & 0.85 \\
\hline \multirow[t]{2}{*}{ Digital } & $15.5 \%$ & $19.9 \%$ & $12.2 \%$ & $21.0 \%$ & 5.78 & .02 & 1.58 & 0.00 & .98 & 1.01 \\
\hline & & & & & & & raction & 0.55 & .46 & 0.75 \\
\hline \multirow[t]{2}{*}{ Both } & $15.7 \%$ & $26.9 \%$ & $28.7 \%$ & $33.0 \%$ & 7.97 & .005 & 1.61 & 6.74 & .009 & 0.56 \\
\hline & & & & & & & raction & 1.78 & .53 & 1.89 \\
\hline
\end{tabular}

Note. Percentages represent overall percentages (without effects of covariates removed) $\cdot \chi^{2}=$ Wald chi-square statistic for main effects and interactions after controlling for potentially confounding demographic characteristics (gender, age, income, first-generation status, year in university, number of courses). OR $=$ odds ratio. 
The students who indicated that they would prefer a printed textbook if cost was not a factor were selected and their reasons for this preference were examined. As shown in the upper portion of Table 5, the majority indicated that they found printed textbooks more convenient to read, easier to write and highlight in, and easier to move to different pages and sections. As shown in the table, hierarchical logistic regression analyses (controlling for differences in demographic characteristics of the groups) indicated there was a great deal of similarity in the four groups' reasons for preferring printed textbooks. The primary difference was that online students were more likely than on-campus students to indicate a preference for printed textbooks because they like to keep a printed copy for later use.

Next, the students who indicated they would prefer a digital textbook if cost were not a factor were selected and the reasons for their preference were examined. As displayed in the lower portion of Table 5, most reported liking that they can access digital textbooks anywhere, that they find it easier to search for terms and other information, they find digital textbooks to be more environmentally friendly, and they find it easier to move to different pages/ sections. There were no significant differences in the four groups' reasons for preferring digital textbooks. 
Table 5

\section{Reason for Preference (Assuming Cost Is Not a Factor)}

\begin{tabular}{|c|c|c|c|c|c|c|c|c|c|c|}
\hline & \multicolumn{2}{|c|}{ On campus } & \multicolumn{2}{|c|}{ Online } & \multicolumn{6}{|c|}{ Main effects and interactions } \\
\hline & \multirow{2}{*}{$\begin{array}{c}\text { Traditional } \\
\mathrm{N}=249\end{array}$} & \multirow{2}{*}{$\begin{array}{r}\text { Open } \\
\mathrm{N}=107\end{array}$} & \multirow{2}{*}{$\begin{array}{c}\text { Traditional } \\
\mathrm{N}=107\end{array}$} & \multirow{2}{*}{$\begin{array}{c}\text { Open } \\
\mathrm{N}=81\end{array}$} & \multicolumn{3}{|c|}{ Main effect textbook } & \multicolumn{3}{|c|}{ Main effect environment } \\
\hline Reasons prefer printed & & & & & $\chi^{2}$ & $\mathrm{p}$ & OR & $\chi^{2}$ & $\mathrm{p}$ & OR \\
\hline \multirow[t]{2}{*}{ More convenient to read } & $85.9 \%$ & $79.4 \%$ & $74.8 \%$ & $82.7 \%$ & 0.00 & .99 & 1.00 & 0.00 & .99 & 1.00 \\
\hline & & & & & & \multicolumn{2}{|c|}{ Interaction } & 3.58 & .06 & 1.74 \\
\hline \multirow[t]{2}{*}{ To write in and/ or highlight } & $78.3 \%$ & $73.8 \%$ & $67.3 \%$ & $75.3 \%$ & 0.03 & .87 & 1.04 & 0.69 & .41 & 1.30 \\
\hline & & & & & & \multicolumn{2}{|c|}{ Interaction } & 1.62 & .20 & 0.56 \\
\hline \multirow[t]{2}{*}{ Easier to move to different pages/ sections } & $78.3 \%$ & $72.0 \%$ & $74.8 \%$ & $85.2 \%$ & 0.01 & .91 & 1.03 & 0.17 & .68 & 1.15 \\
\hline & & & & & & \multicolumn{2}{|c|}{ Interaction } & 3.97 & .05 & 0.37 \\
\hline \multirow[t]{2}{*}{ To keep printed copy for later use } & $34.1 \%$ & $27.1 \%$ & $47.7 \%$ & $55.6 \%$ & 0.14 & .71 & 0.93 & 4.76 & .03 & 0.54 \\
\hline & & & & & & \multicolumn{2}{|c|}{ Interaction } & 0.08 & .77 & 0.66 \\
\hline \multirow{4}{*}{$\begin{array}{l}\text { Some digital texts are not compatible with my } \\
\text { print disability solutions } \\
\text { Don't have access to technology to use digital } \\
\text { texts }\end{array}$} & $4.8 \%$ & $7.5 \%$ & $6.5 \%$ & $8.6 \%$ & 0.19 & .66 & 1.18 & 1.14 & .28 & 0.58 \\
\hline & & & & & & \multicolumn{2}{|c|}{ Interaction } & 0.03 & .87 & 0.88 \\
\hline & $2.0 \%$ & $1.9 \%$ & $3.7 \%$ & $4.9 \%$ & 0.48 & 0.49 & 1.50 & 1.97 & .16 & 0.35 \\
\hline & & & & & & \multicolumn{2}{|c|}{ Interaction } & 0.02 & .89 & 1.18 \\
\hline Reasons prefer digital & $\mathrm{N}=56$ & $\mathrm{~N}=40$ & $\mathrm{~N}=22$ & $\mathrm{~N}=37$ & $\chi^{2}$ & $\mathrm{p}$ & OR & $\chi^{2}$ & $\mathrm{p}$ & OR \\
\hline \multirow[t]{2}{*}{ Can access it anywhere } & $80.4 \%$ & $82.5 \%$ & $90.9 \%$ & $89.2 \%$ & 0.03 & .85 & 1.10 & 1.52 & .22 & 0.36 \\
\hline & & & & & & \multicolumn{2}{|c|}{ Interaction } & 0.00 & .96 & 1.05 \\
\hline \multirow{2}{*}{$\begin{array}{l}\text { Easier to search for terms and other } \\
\text { information }\end{array}$} & $76.8 \%$ & $70.0 \%$ & $90.9 \%$ & $83.8 \%$ & 1.05 & .31 & 0.63 & 4.26 & .04 & 0.23 \\
\hline & & & & & & \multicolumn{2}{|c|}{ Interaction } & 0.06 & .80 & 1.30 \\
\hline \multirow[t]{2}{*}{ More cost effective } & $62.5 \%$ & $57.5 \%$ & $81.8 \%$ & $75.7 \%$ & 0.48 & .49 & 0.76 & 0.96 & .33 & 0.57 \\
\hline & & & & & & \multicolumn{2}{|c|}{ Interaction } & 0.02 & .88 & 1.13 \\
\hline \multirow[t]{2}{*}{ More environmentally friendly } & $64.3 \%$ & $60.0 \%$ & $68.2 \%$ & $62.2 \%$ & 0.52 & .47 & 0.76 & 0.00 & .98 & 1.01 \\
\hline & & & & & & \multicolumn{2}{|c|}{ Interaction } & 0.00 & .96 & 1.04 \\
\hline \multirow[t]{2}{*}{ Easier to move to different pages/ sections } & $51.8 \%$ & $47.5 \%$ & $63.6 \%$ & $54.1 \%$ & 0.00 & .99 & 1.00 & 1.07 & .30 & 0.59 \\
\hline & & & & & & \multicolumn{2}{|c|}{ Interaction } & 0.00 & .99 & 1.00 \\
\hline More accustomed to reading online & $44.6 \%$ & $32.5 \%$ & $50.0 \%$ & $51.4 \%$ & 1.81 & .18 & 0.60 & 2.55 & .11 & 0.44 \\
\hline & & & & & & Int & action & 0.92 & .76 & 0.80 \\
\hline
\end{tabular}


Note. Percentages represent overall percentages (without effects of covariates removed). $\chi^{2}=$ Wald chi-square statistic for main effects and interactions after controlling for potentially confounding demographic characteristics (gender, age, income, first-generation status, year in university, number of courses). OR = odds ratio. 
The group of students assigned an open textbook was then selected and independent samples t-tests were used to compare on-campus and online students' responses to the statement, "I would have preferred to purchase a traditional textbook for this course." The results revealed no significant differences in oncampus $(\mathrm{M}=2.05, \mathrm{SE}=.09)$ and online $(\mathrm{M}=2.05, \mathrm{SE}=.10)$ students' ratings, $\mathrm{t}=0.01, \mathrm{p}=.99, \mathrm{~d}=0$. Next, the group of students assigned a traditional textbook was selected and independent samples t-tests were used to compare on-campus and online students' responses to the statement, "I would have preferred a free digital textbook for this course." The results revealed that on-campus students gave significantly stronger ratings of agreement $(\mathrm{M}=4.06, \mathrm{SE}=.06)$ than online students $(\mathrm{M}=3.68, \mathrm{SE}=.10), \mathrm{t}=-3.38, \mathrm{p}<.001, \mathrm{~d}$ $=0.30$.

\section{Importance of Textbook Features}

Finally, a MANCOVA was used to compare the four groups of students' ratings on the importance of various textbook features. As before, this analysis was done while controlling for potentially confounding demographic variables. The results revealed a significant overall main effect of environment (on-campus versus online), Wilks $\lambda=0.96, \mathrm{~F}=4.59, \mathrm{p}<.001, \eta_{\mathrm{p}}{ }^{2}=.04$, but no main effect of textbook type (open versus traditional), Wilks $\lambda=0.99, \mathrm{~F}=0.38, \mathrm{p}=.89, \eta_{\mathrm{p}}{ }^{2}=.004$, and no environment $\mathrm{x}$ textbook interaction, Wilks $\lambda=0.99, F=0.74, p=.62, \eta_{p}^{2}=.007$. As shown in Table 6 , the results of follow-up, one-way analyses of covariance (ANCOVAs) on the main effect of environment revealed that online students rated the importance of immediate access, convenience and portability, ability to print, and ability to keep forever significantly higher than did on-campus students.

Table 6

Ratings of the Importance of Various Features of Textbooks across the Four Groups

\begin{tabular}{|c|c|c|c|c|c|c|c|}
\hline & \multicolumn{2}{|c|}{ On campus } & \multicolumn{2}{|c|}{ Online } & & & \\
\hline & \multirow{3}{*}{$\begin{array}{c}\text { Traditional } \\
\mathrm{N}=147\end{array}$} & \multirow{3}{*}{$\begin{array}{c}\text { Open } \\
\mathrm{N}=186\end{array}$} & \multirow{3}{*}{$\begin{array}{c}\text { Traditional } \\
\mathrm{N}=163\end{array}$} & \multirow{3}{*}{$\begin{array}{c}\text { Open } \\
\mathrm{N}=161\end{array}$} & \multirow{2}{*}{\multicolumn{3}{|c|}{$\begin{array}{c}\text { Main effect } \\
\text { environment }\end{array}$}} \\
\hline & & & & & & & \\
\hline & & & & & $\mathrm{F}$ & $\mathrm{p}$ & $\eta_{p}^{2}$ \\
\hline Immediate access & $3.96(0.07)$ & $4.07(0.07)$ & $4.23(0.70)$ & $4.24(0.07)$ & 7.07 & .008 & .01 \\
\hline Price & $4.01(0.09)$ & $4.02(0.08)$ & $4.00(0.08)$ & $4.06(0.08)$ & 0.01 & .92 & .000 \\
\hline $\begin{array}{l}\text { Convenience } \& \\
\text { portability }\end{array}$ & $3.84(0.08)$ & $3.87(0.07)$ & $4.15(0.08)$ & $4.09(0.07)$ & 8.57 & .004 & .01 \\
\hline Ability to print & $3.03(0.11)$ & $2.97(0.10)$ & $3.21(0.11)$ & $3.35(0.11)$ & 4.73 & .03 & .007 \\
\hline Ability to keep forever & $2.49(0.11)$ & $2.39(0.10)$ & $2.68(0.11)$ & $2.76(0.11)$ & 4.59 & .03 & .007 \\
\hline Ability to share it & $2.52(0.10)$ & $2.44(0.09)$ & $2.19(0.10)$ & $2.37(0.10)$ & 2.88 & .09 & .004 \\
\hline
\end{tabular}

Note. Marginal means (with effects of covariates controlled) are presented with standard errors in parentheses. 1 indicates no importance at all, 2 indicates of little importance, 3 indicates of average importance, 4 indicates very important, 5 indicates absolutely essential. F statistics represent comparisons of the two groups after controlling for differences in demographic characteristics (gender, age, first-generation status, year in university, number of courses). $\eta_{p}^{2}=$ partial eta squared (effect size indicator). 


\section{Discussion}

This study corroborated previous studies showing the detrimental impacts of the high costs of course materials and the heavy use of strategies to offset these costs. However, this study further explicated these results by showing that online and on-campus students may haveseparate strategies for avoiding high costs, with on-campus students more frequently skipping out on purchasing expensive textbooks and online students more frequently skipping out on specific courses. Online students also proved more likely than oncampus students to purchase textbooks from non-bookstore vendors and to rent textbooks, while oncampus students were more likely than online students to report buying used copies from the campus bookstore and sharing books with classmates. These disparate strategies are understandable given the demographics and context at hand. Students working online have less immediate access to instructors, campus bookstores, and classmates. As such, online students may depend more on the explanations provided by textbooks and have fewer opportunities to purchase used copies and share textbook costs with their peers. Therefore, while both groups reported heavy use of strategies to offset high textbook costs, differences in learning environments may affect the options available for students to adopt specific strategies.

Results of this study align with previous work by showing students' preferences for both free digital texts and print resources (if cost were not a factor). Because the study collected responses from students using different types of textbooks (traditional and open), it not only provided insight about the needs of online and on-campus students, it also provided insight about how students respond in general to course materials in different formats. Not surprisingly, students who used an open textbook were 40 times less likely to report utilizing the option to print their textbook and 31.5 times more likely to report having used their textbook in its native digital format than students who were assigned traditional textbooks. Of greater interest, students who were assigned open textbooks were two times more likely to report preferring a free digital textbook and 2.63 times less likely to prefer a printed textbook than students assigned a traditional textbook. Students in classes using open textbooks were also more likely to report preferring digital textbooks over printed textbooks, assuming cost is not a factor. These results showing overall preferences for free digital materials are understandable, given students' sensitivity to cost in both on-campus and online contexts. However, the results also suggest that students may develop different preferences following exposure to open textbooks. That is, students may be more open to the use of open textbooks after they have experience with them. This finding should be examined more closely in future research using a longitudinal within-subjects design.

Although general preferences for print and digital materials did not vary as a function of the learning environment, differences in online and on-campus students' preferences emerged when they were asked to assume cost was not a factor. Specifically, when cost was not a factor, on-campus students were 1.58 times more likely than online students to report preferring printed textbooks, while online students were 1.78 times more likely than on-campus students to report preferring using both formats in their courses. Nevertheless, online students assigned a traditional textbook gave lower ratings of agreement to the statement, "I would have preferred a free digital textbook for this course," than on-campus students assigned a traditional textbook, and online students rated the ability to print as a more important feature than on-campus students. These findings may be explained, in part, by the students' unique contexts. 
Online students may find themselves with a greater proliferation of online content that they must juggle while studying and completing assessments. As a result, they may show a greater preference for mixed material types out of convenience and due to a lack of-or discomfort with-multiple screen interfaces. These findings underscore the importance of ensuring that online students have the option to use OER in both digital and printed formats. When it came to course materials, online students also placed a greater emphasis than on-campus students on the ability to keep the materials forever, and on immediate access, convenience, and portability. These differences may be explained by increased planning and foresight in the more mature cohort of online students, delays online students often experience in receiving their course materials from the campus bookstore, as well as differences in convenient access to instructors. These differences may also reflect differences in lifestyle that makes convenience and portability more important to the older, higher-earning students who predominated in the online courses examined in this study.

\section{Limitations and Strengths}

Confounding factors in this study included gender, income, first-generation status, age, year in university, and number of courses in which students had enrolled. These factors were accounted for in analyses but merit mention. Instructors as a confounding factor could not be accounted for in this study due to insufficient information in surveys; however, because multiple textbooks were used in the study, the relative strength or weakness of the textbook likely acted less as a confounding factor than it might have in one-toone OER and traditional textbook comparisons. An additional strength of this study was its $2 \times 2$ design, which permitted comparisons between groups using traditional and open textbooks. The survey instrument used in the study also reached a fairly sizeable group of students, and the incentive used to motivate participation produced a high response rate, indicative of less biased results. However, additional studies could examine perceptions of a still larger pool of students on and off campus-including students taking courses in other disciplines and at other institutions of higher education.

\section{Conclusion}

This study supported previous findings, showing the negative impacts of the high costs of course materials and students' preferences for print materials (if costs were no barrier). The study was unique in showing the differing needs of online and on-campus students, with online students proving to be less likely than on-campus students to opt out of purchasing a textbook and more likely to opt out of specific courses. These students also rated having immediate access to course materials, convenience and portability, the ability to print, and the ability to keep materials forever as significantly more important than on-campus students. Once again, these findings highlight the need to allocate resources to support students who are reliant on print or have a predilection toward studying with print.

The inclusion of comparison groups of students using traditional textbooks in this study further afforded the opportunity to explore potential impacts of open textbook usage, revealing that students who had used OER were more desirous of using digital content as compared to students who had used traditional texts. These results suggest that open textbooks may make students more open to engaging with digital textbooks, 
and/ or that some reluctance to digital textbooks may stem from a lack of experience with that format. Future research might therefore productively investigate the impact on student preferences of having been exposed to OER. More generally, this study illustrates how campuses can continue supporting students with diverse needs, and how OER researchers can continue to study perceptions and impacts in diverse student groups.

\section{Acknowledgements}

The authors thank the William and Flora Hewlett Foundation and the Open Education Group for sponsoring the OER fellowship that supported this work, and J ohn Hilton, III, for his guidance and review of a draft of this manuscript. 


\section{References}

Bliss, T., Robinson, T. J ., Hilton, J ., \& Wiley, J . (2013). An OER COUP: College teacher and student perceptions of open educational resources. J ournal of Interactive Media in Education, 2013(1), 125. http:/ / doi.org/ 10.5334/ 2013-04

Buzzetto-More, N., Guy, R., \&Elobaid, M. (2007). Reading in a digital age: e-books are students ready for this learning object? LearnTechLib, 3(1), 239-250. http:// doi.org/ 10.28945/ 397

Colvard, N. B., Watson, C. E., \& Park, H. (2018). The impact of open educational resources on various student success metrics. International J ournal of Teaching and Learning in Higher Education, 30(2), 262-276. Retrieved from http:// www.isetl.org/ijtlhe/ pdf/ IJ TLHE3386.pdf

Cooney, C. (2017). What impacts do OER have on students? Students share their experiences with a health psychology OER at New York City College of Technology. The International Review of Research in Open and Distance Learning, 18(4), 155-178. http:// dx.doi.org/ 10.19173/irrodl.v18i4.3111

Feldstein, A., Martin, M., Hudson, A., Warren, K., Hilton, J ., \&Wiley, D. (2012). Open textbooks and increased student access and outcomes. European J ournal of Open, Distance and E- Learning, 2, 1-9. Retrieved from https:// oerknowledgecloud.org/ content/ open-textbooks-and-increasedstudent-access-and-outcomes

Florida Virtual Campus. (2016). 2016 student textbook and course materials survey. Retrieved from https:// florida.theorangegrove.org/ og/ items/ 3a65c507-2510-42d7-814c-ffdefd394b6c/ 1/

Hendricks, C., Reinsberg, S., \& Rieger, G. (2017). The adoption of an open textbook in a large physics course: An analysis of cost, outcomes, use, and perceptions. The International Review of Research in Open and Distributed Learning, 18(4). Retrieved from http:// www.irrodl.org/index.php/irrodl/article/view/3006/4220

Hilton, J . (2016). Open educational resources and college textbook choices: A review of research on efficacy and perceptions. Educational Technology Research and Development, 64, 573-590. https:// doi.org/ 10.1007/ s11423-016-9434-9

Hilton, J., Robinson, T.J ., Wiley, D., \&Ackerman, J .D. (2014). Cost-savings achieved in two semesters through the adoption of open educational resources. The International Review of Research in Open and Distributed Learning, 15(2). Retrieved from http:// www.irrodl.org/index.php/irrodl/article/view/ 1700/ 2833

Illowsky, B. S., Hilton, J ., Whiting, J ., \&Ackerman, J . D. (2016). Examining student perception of an open statistics book. Open Praxis, 8(3), 265-276. http:// dx.doi.org/ 10.5944/ openpraxis.8.3.304 
J hangiani, R., Dastur, F., Le Grand, R., \& Penner, K. (2018). As good or better than commercial textbooks: Students' perceptions and outcomes from using open digital and open print textbooks. Canadian J ournal for the Scholarship of Teaching and Learning, 9(1). https:/ / doi.org/ 10.5206/ cjsotlrcacea.2018.1.5

J hangiani, R., \&J hangiani, S. (2017). Investigating the perceptions, use, and impact of open textbooks: A survey of post-secondary students in British Columbia. The International Review of Research in Open and Distributed Learning, 18(4). Retrieved from http:// www.irrodl.org/index.php/irrodl/article/ view/ 3012/4214

Lindshield, B., \&Adhikari, K. (2013). Online and campus college students like using an open educational resource instead of a traditional textbook. J ournal of Online Learning \& Teaching, 9(1), 1-7. Retrieved from http://jolt.merlot.org/vol9no1/lindshield_0313.htm

Millar, M., \& Schrier, T. (2015). Digital or printed textbooks: Which do students prefer and why? J ournal of Teaching in Travel \& Tourism, 15(2), 166-185. https:// doi.org/ 10.1080/ 15313220.2015.1026474

Ozdemir, O., \& Hendricks, C. (2017). Instructor and student experiences with open textbooks, from the California open online library for education (Cool4Ed). J ournal of Computing in Higher Education, 29, 98-113. https:// doi.org/ 10.1007/ s12528-017-9138-0

Petrides, L., Jimes, C., Middleton-Detzner, C., Walling, J ., \&Weiss, S. (2011). Open textbook adoption and use: Implications for teachers and learners. Open Learning: The J ournal of Open, Distance, and e-Learning, 26(1), 39-49. https:/ / doi.org/ 10.1080/02680513.2011.538563

Popken, B. (2015). College textbook prices have risen 1,041 percent since 1977 [Blog post]. NBC News. Retrieved from https:// www.nbcnews.com/ feature/ freshman-year/ college-textbook-prices-haverisen-812-percent-1978-n399926

Rockinson-Szapkiw, A., Courduff, J ., Carter, K., \&Bennett, D. (2013). Electronic versus traditional print textbooks: A comparison study on the influence of university students' learning. Computers \& Education, 63, 259-266. https:// doi.org/ 10.1016/j.compedu.2012.11.022

Shepperd, J ., Grace, J ., \& Koch, E. (2008). Evaluating the electronic textbook: Is it time to dispense with the paper text? Teaching of Psychology, 35(1), 2-5. https:// doi.org/ 10.1080/00986280701818532

UNESCO. (2017). Open Educational Resources (OER). Retrieved from http:// www.unesco.org/ new/ en/ communication-and-information/access-to-knowledge/ openeducational-resources/

Woody, W., Daniel, D., \& Baker, C. (2010). E-books or textbooks: Students prefer textbooks. Computers \&Education, 55, 945-948. https:// doi.org/ 10.1016/j.compedu.2010.04.005 
Open to Open? An Exploration of Textbook Preferences and Strategies to Offset Textbook Costs for Online Versus On-Campus Students Anderson and Cuttler

Athabasca

University

(c) 